\title{
Poly (butylene succinate) scaffolds prepared by leaching
}

\begin{abstract}
In recent years there was an increase in the development of new materials for use in bioengineering mainly related to bone tissue substitutes. A myriad of natural or synthetic materials can be used, such as polymers, ceramics, metals, and composites. In this work, the functionality of poly (butylene succinate), PBS, in producing scaffolds by leaching was studied. PBS is an aliphatic biopolyester, which presents excellent mechanical and osteoconductive properties. PBS is biocompatible, can allow cell adhesion and proliferation in vivo and in vitro as well. Production of scaffolds was performed using a circular die of $1 \mathrm{~mm}$ thickness and $8.5 \mathrm{~mm}$ diameter, using a hydraulic hot press. The porosity of the scaffolds was reached by the preparation of mixtures with different concentrations of PBS and $\mathrm{NaCl}$. The samples were characterized aiming to observe the formation of the pores. Besides that, the material behavior depending on temperature was also performed. The obtained results allowed inferring that leaching is a fast, little expensive and efficient way to prepare PBS scaffolds.
\end{abstract}

Keywords: scaffolds, PBS, leaching, $\mathrm{NaCl}$
Volume I Issue 6 - 2017

\author{
Diana Daniel Pérez,' Jacqueline Silva \\ Cardoso Lunz,' Edson Rodrigo Fernandes \\ dos Santos, ${ }^{2}$ Geiza Esperandio de Oliveira, ${ }^{2}$ \\ Edgar Francisco Oliveira de Jesus, ${ }^{3}$ Fernando \\ Gomes de Souza Junior ${ }^{1,2}$ \\ 'Instituto de Macromoléculas, Centro de Tecnologia-Cidade \\ Universitária, Universidade Federal de Rio de Janeiro, Brazil \\ 2Programa de Engenharia Civil, Centro de Tecnologia-Cidade \\ Universitária, Universidade Federal de Rio de Janeiro, Brazil \\ ${ }^{3}$ Programa de Engenharia Nuclear, Centro de Tecnologia-Cidade \\ Universitária, Universidade Federal de Rio de Janeiro, Brazil
}

\begin{abstract}
Correspondence: Fernando G de Souza Jr, Universidade Federal do Rio de Janeiro, Cidade Universitária. Av. Horacio Macedo, 2.030, Centro de Tecnologia-Prédio do Bloco J CEP 2194I-598-Rio de Janeiro-RJ-Brazil,Tel 0055 2l 3938 7766, Email fgsj@ufrj.br
\end{abstract}

Received: October 28, 2017 | Published: December 18, 2017
Abbreviations: PBS, poly (butylene succinate); Tg, glass temperature; Tm, melting temperature; PLA, polylactic acid; PCL, poly caprolactone; PGA, poly glycolic acid; PHB, poly hydroxy butyrate acid; $\mathrm{NaCl}$, sodium chloride; FTIR, fourier transform infrared spectroscopy; STA, simultaneous thermal analysis; SEM, scanning electron microscopy; $\mu \mathrm{CT}$, computerized micro tomography; PHB, poly hydroxy butyrate acid

\section{Introduction}

Biomaterials are the main focuses of scientists' efforts to develop new materials to replace or repair bone tissues. ${ }^{1}$ Biomaterials are natural or synthetic materials which can interface with biological systems allowing the increase, repair or even the replacement of tissues and organs of the human body. ${ }^{2}$ Within biomaterials, the polymers can be natural or synthetic as well. The main polymers used to repair bone tissue are the polyglycolic acid (PGA), polylactic acid (PLA), polyhydroxybutyrate acid (PHB) and polycaprolactone (PCL). ${ }^{3-5}$ These polymers are useful to the "scaffolds" development in the bone tissue engineering field, acting as templates for the formation of new tissues. For this, these materials must present specific requirements such as adequated internal architecture and surface properties, besides mechanical resistance and porosity. ${ }^{6,7}$ These biodegradable templates must be porous to the highly efficient propagation of cells and nutrients, and also for supplying oxygen. ${ }^{8}$ Besides that, these pores should be three-dimensionally interlinked, allowing the proliferation of new bone tissue and facilitating fluid transport through the material. ${ }^{9} \mathrm{~A}$ wide variety of natural and synthetic materials are being investigated for the design and construction of scaffolds for bone tissue engineering. Among them, the most remarkable are the natural polymers, such as gelatin, agar, fibrin or collagen; the synthetic bioresorbable polymers, such as polylactic acid (PLA), polycaprolactone (PCL); and, finally, the porous ceramics, such as bioglass and calcium phosphate structures as well as the natural ceramics, such as coral. ${ }^{10-12}$ In this context, the poly (butylene succinate), PBS is a biodegradable aliphatic biopolyester. When compared to other similar polymers, PBS presents improved mechanical and processing properties. PBS also presents biocompatibility, being an osteoconductive material which allows cell adhesion. Literature shows PBS associated with other polymers as an efficient matrix to the preparation of scaffold. ${ }^{13-16}$ Mostly, expensive techniques, such as electro-spinning, are used to the preparation of these materials. ${ }^{16}$ Thus, PBS was used here to prepare scaffolds by leaching using $\mathrm{NaCl}$ as a cheap porogenic agent. The obtained materials were characterized using several techniques, and the results allowed inferring that leaching is a fast, little expensive and efficient way to prepare PBS scaffolds.

\section{Materials and methods}

\section{Materials}

Poly (1,4-butylene succinate), Lot\#MKBQ7938V and sodium chloride were purchased from Sigma-Aldrich. All materials were used as received.

\section{Methods}

Scaffolds preparation: Scaffolds were prepared as disks of $1 \mathrm{~mm}$ thick and $8.5 \mathrm{~mm}$ diameter by hot molting under pressure $\left(130^{\circ} \mathrm{C} @ 5 \mathrm{M}-\right.$ $\mathrm{Pa}$ ). For assure the formation of the pores, different amounts of $\mathrm{NaCl}$ were mixed to the PBS. The used proportions between PBS and $\mathrm{NaCl}$ were equal to $1: 0.10,1: 0.25$ and 1:0.50. These proportions allowed preparing PBS filled with 9.1, 20.0 and $33.3 \mathrm{wt} \%$ of $\mathrm{NaCl}$, respectively. The leaching was performed in deionized water. Drying took place at room temperature for 24 hours. 
Characterization: Fourier transform infrared spectroscopy using attenuated total reflectance (FTIR-ATR) analyses were performed in a Perkin-Elmer 1720X Fourier transform spectrometer. The FTIR spectra were obtained using ATR (diamond crystal) in an inert atmosphere, with a resolution of $4 \mathrm{~cm}^{-1}$ in the range $4000-675 \mathrm{~cm}^{-1}$. Stored results were averages of 124 scans. Simultaneous Thermal Analysis (STA) was performed using a PerkinElmer STA 6000. Measurements were carried out under nitrogen at a heating rate of $20^{\circ} \mathrm{C} / \mathrm{min}$ up to $700^{\circ} \mathrm{C}$ with a gas flow rate of $20 \mathrm{~mL} / \mathrm{min}$. Scanning electron microscopy (SEM) experiments were performed with a JEOL JSM-5610 LV microscope, using acceleration voltage of $15 \mathrm{kV}$. Samples were coated with gold to study the morphology of the prepared materials. Computerized Microtomography $(\mu \mathrm{CT})$ scaffolds were analyzed by $\mu \mathrm{CT}$ (SKYSCAN), with a detection array of 2240x2240 pixels, Voltage $40 \mathrm{kV}$, Current $160 \mu \mathrm{A}$, Aluminum Filter $1 \mathrm{~mm}$, Rotation Degree $0.6^{\circ}$, Pixel Size 7, $12 \mu \mathrm{m}$, Acquisition time $1 \mathrm{~h}$ and 50 minutes.

\section{Result and discussion}

PBS spectra of PBS and PBS: $\mathrm{NaCl}$ composites are shown in Figure 1. The dublets at 1331 and $1317 \mathrm{~cm}^{-1}$ are attributed to the symmetric and asymmetric deformational vibrations of $\mathrm{CH}_{2}$ groups in the main chain of PBS, respectively. The bands around 1155 and
$1243 \mathrm{~cm}^{-1}$ correspond to stretching of the -COC- bonds in the ester group. ${ }^{17}$ The band at $1714 \mathrm{~cm}^{-1}$ is related to stretching vibrations of the ester group in PBS, specifically in the $\mathrm{C}=\mathrm{O}$ bonds of the carbonyl. The peaks in the $1044 \mathrm{~cm}^{-1}$ region are related to the stretching vibrations of O-C-C bonds in this polymer. ${ }^{18}$ It is also possible to notice a band at $917 \mathrm{~cm}^{-1}$ corresponding to vinyl groups. The occurrence of terminal vinyl groups is attributed to the degradation reaction of the PBS chain. ${ }^{19,20}$ Composites, in comparison with pure PBS, do not present changes in their FTIR spectra simply because $\mathrm{NaCl}$ does not absorb in the IR region.

The Table 1 shows the density of the prepared materials after leaching. The density analysis demonstrated that the use of increasing $\mathrm{NaCl}$ amounts produced a decrease of the final density and the increase of the pores in the materials. The thermal analyzes results are also shown in Table 1. The TGA and DSC were used to determine the effect of the pores on the thermal properties of the materials. The scaffolds presented melting and degradation temperatures equal to $(119 \pm 2)^{\circ} \mathrm{C}$ and $(400 \pm 5)^{\circ} \mathrm{C}$, respectively. Besides that, data shown in Table 1 allows inferring correlations between density and melting and degradation enthalpies equal to 0.87 and 0.81 , respectively. Thus, as the pores volume increase, the density decreases as well as the energy necessary to the melting and degradation.

Table I Apparent density and main thermal properties of the scaffolds

\begin{tabular}{llll}
\hline Sample & Density $\left(\mathbf{g} / \mathrm{cm}^{3}\right)$ & Melting enthalpy $(\mathbf{J} / \mathbf{g})$ & Degradation enthalpy $(\mathrm{J} / \mathbf{g})$ \\
\hline PBS & $1.1617 \pm 0.0108$ & $53.9 \pm 0.7$ & $397.1 \pm 5.4$ \\
PBS: $\mathrm{NaCl} 1: 0.10$ & $1.1483 \pm 0.0259$ & $46.3 \pm 0.6$ & $341.0 \pm 4.6$ \\
PBS: $\mathrm{NaCl} 1: 0.25$ & $1.1089 \pm 0.4374$ & $40.8 \pm 0.5$ & $337.2 \pm 4.5$ \\
PBS: $\mathrm{NaCl} 1: 0.50$ & $1.0232 \pm 0.0243$ & $37.4 \pm 0.5$ & $309.8 \pm 4.2$ \\
\hline
\end{tabular}

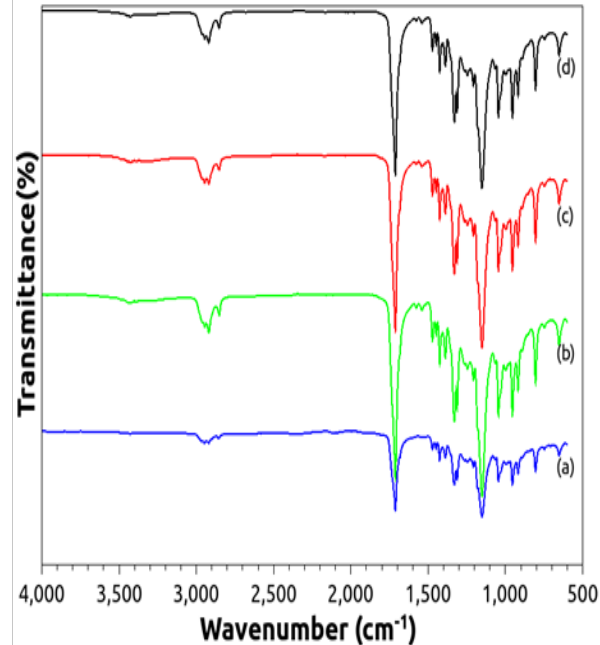

Figure I (A) FTIR spectra of PBS (B) PBS: $\mathrm{NaCl}$ I:0.10 (C ) I:0.25 and (D) I:0.50.

Scanning Electron Microscopy (SEM) images, shown in Figure 2 , allowed inferring the increase of the pores number as more and more $\mathrm{NaCl}$ was used in the composites. Besides that, the diameter of pores was calculated. Samples filled with 10,25 and $50 \mathrm{phr}$ of $\mathrm{NaCl}$ presented average surface diameter of pores equal to $136 \pm 58 \mu \mathrm{m}$, $232 \pm 33 \mu \mathrm{m}$, and $231 \pm 84 \mu \mathrm{m}$, respectively. Thus, the increase of used $\mathrm{NaCl}$ also produced an increase of the pore size and distribution. In turn, the microtomography of the scaffolds of PBS with $50 \mathrm{phr}$ of $\mathrm{NaCl}$ after leaching is shown in Figure 3. The average pore diameter was also calculated. The smaller set of pores presented an average diameter equal to $329 \pm 94 \mu \mathrm{m}$. This result is statistically equal to the one obtained from SEM. On the other hand, the microtomography also allowed inferring the presence of macropores, which presented an average diameter equal to $1831 \pm 515 \mu \mathrm{m}$. Despite microtomography image shown non-homogeneous distribution of pores in certain parts of the scaffold, it proves the presence of pores (in blue) inside the scaffolds and the interconnectivity among them.
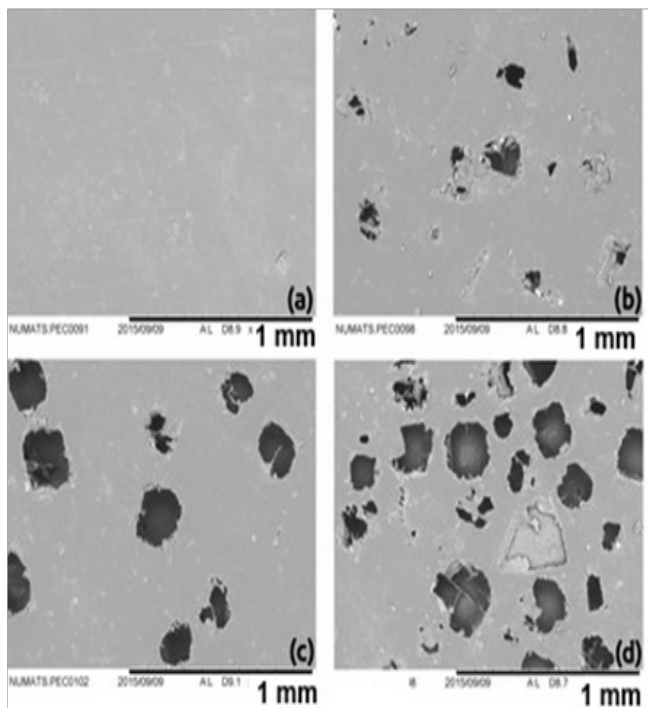

Figure 2 (A) Scanning Electron Microscopy of PBS (B) PBS: $\mathrm{NaCl}$ I:0.10 (C) I:0.25 and (D) I:0.50. 


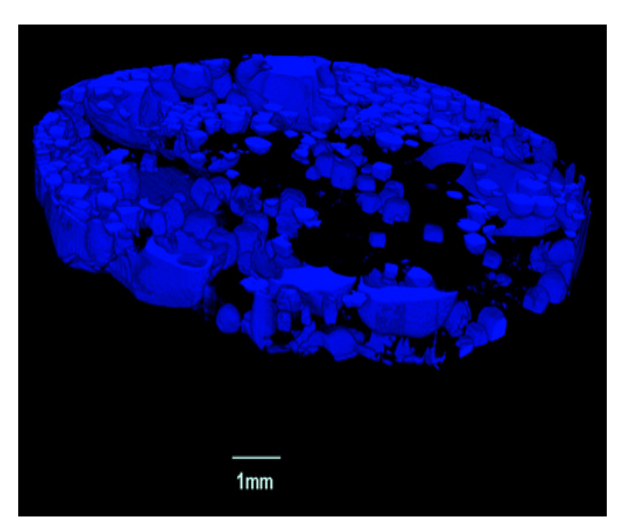

Figure 3 Computerized microtomography $(\mu \mathrm{CT})$ of the scaffolds of PBS: $\mathrm{NaCl}$ I:0.50.

\section{Conclusion}

This is a preliminary study on PBS based scaffolds, further detailed investigations are in progress and will be reported later. Thus, this work allowed proving that the production of scaffolds based on PBS by the leaching method is efficient. Therefore, this is another application for PBS, which is a platform polymer and will be more and more used as its price falls making this polymer even more present in our lives.

\section{Acknowledgements}

The authors thank to Conselho Nacional de Desenvolvimento Científico e Tecnológico (CNPq), Coordenação de Aperfeiçoamento de Pessoal de Nível Superior (CAPES), Financiadora de Estudos e Projetos (FINEP PRESAL Ref.1889/10) and Fundação Carlos Chagas Filho de Amparo à Pesquisa do Estado do Rio de Janeiro (FAPERJ) for the financial support and scholarships.

\section{Conflict of interest}

The author declares no conflict of interest.

\section{References}

1. Keane T, Badylak SF. Biomaterials for tissue engineering applications. Seminars in Pediatric surgery. 2014;23:112-118

2. San Martin Ra. Substitutos oseos en ortopedia. Las sales de calcio y la matriz óssea desmineralizada. Revista mexicana de ortopedia pediatrica. 2014;16(1):11-19

3. Macêdo Moc, Macêdo Hra, Neto Abn, et al. Estudo da porosidade de arcabouços de Ti-NB $\mathrm{NB}_{2} 5$-SN para aplicação biomédica. Revista Brasileira de Inovação Tecnológica em Saúde [S.I.]; 2011.

4. Peñaranda-Armbrecht J, Agudelo C, Zuluaga F, et al. Synthesis of poly (lactic acid) and production of scaffolds by electrospinning. MOJ Proteomics Bioinform. 2016;4(6):00140.

5. Sarkar S, Baker BA, ChenD, et al. Roles of nanofiber scaffold structure and chemistry in directing human bone marrow stromal cell response. Adv Tissue Eng Regen Med Open Access. 2016;1(1):00003
6. Nerantzaki M, Filippousi M, Tendeloo Gv, et al. Novel poly(butylene succinate) nanocomposites containing strontium hydroxyapatite nanorods with enhanced osteoconductivity for tissue engineering applications. EXPRESS Polymer Letters. 2015;9:773-789.

7. Ghorbani S, Hossein E. Treatment of neurodegenerative diseases with using of stem cells/scaffolds. MOJ Anat Physiol. 2016;2(6):00065.

8. Yoon SN, Jun JY, Tae GP. A novel fabrication method of macroporous biodegradable polymer scaffolds using gas foaming salt as a porogen additive. J Biomed Mater Res. 2000;53(1):1-7.

9. Marina OCM, Haroldo RAM, Arlindo BNN, et al. Estudo da porosidade de arcabouços de Ti-NB o 5 -SN para aplicação biomédica. Revista Brasileira de Inovação Tecnológica em Saúde [S.I.]; 2011.

10. Fontes Ram. Fabricação e Caracterização de scaffolds à Base de Fosfatos de Cálcio. Dissertação para obtenção do Grau de Mestre em Engenharia Mecânica em universidade de Lisboa; 2010. p. 1-98.

11. Zavaglia Cac, Silva MHP. Feature Article: Biomaterials. Reference Module in Materials Science and Materials Engineering. 2015;8:112-121.

12. Kanimozhi K, Basha Sk, Kumari VS. Processing and characterization of chitosan/PVA and methylcellulose porous scaffolds for tissue engineering. Materials Science and Engineering Chemical. 2016;61:484-491.

13. Costa-Pinto AR, Correlo VM, Sol PC, et al. Chitosan-poly(butylene succinate) scaffolds and human bone marrow stromal cells induce bone repair in a mouse calvaria model. J Tissue Eng Regen Med. 2012;6(1):2128.

14. Oliveira JT, Crawford A, Mundy JL, et al. Novel melt-processable chitosan-polybutylene succinate fibre scaffolds for cartilage tissue engineering. Journal of Biomaterials Science, Polymer Edition. 2011;22(46):773-788.

15. Tallawi M, Zebrowski DC, Rai R, et al. Poly(glycerol sebacate)/poly(butylene succinate-butylene dilinoleate) fibrous scaffolds for cardiac tissue engineering. Tissue Eng Part C Methods. 2015;21(6):585-596.

16. Llorens E, Ibañez H, del Valle LJ, et al. Biocompatibility and drug release behavior of scaffolds prepared by coaxial electrospinning of poly(butylene succinate) and polyethylene glycol. Materials Science and Engineering: C 49 Supplement C. 2015;49:472-484.

17. Murase Sk, Aymat M, Calvet A, et al. Electrosprayed poly(butylene succinate) microspheres loaded with indole derivatives: A system with anticancer activity. European Polymer Journal. 2015;71:196-209.

18. Kim SJ, Jang DH, Park WH, et al. Fabrication and characterization of 3 dimensional PLGA nanofiber/microfiber composite scaffolds. Polymer. 2010;51(6):1320-1327.

19. Phua YJ, Chow WS, Mohd Ishak Za. Poly(butylene succinate)/organomontmorillonite nanocomposites: effects of the organoclay content on mechanical, thermal, and moisture absorption properties. Journal of Thermoplastic. 2010;24(1):133-151.

20. Ferreira LP, Moreira AN, Souza Jr FG, et al. Preparo de nanocompósitos de poli(succinato de butileno) (PDS) e argila motmorilonita organofílica via polimerização in situ. Polimeros. 2014;24(5):604-611. 